\title{
Highlights of this edition
}

This month's edition is a veritable pot pourri of content and contributors covering topics as diverse as nephrogenic diabetes insipidus to the management of obstetric complications on deployment and from Australia to Belgium.

I would take this opportunity to highlight the newest type of submission accepted by the Journal, 'Images in Practice'. This is an image or video of some aspect of contemporaneous clinical practice with a (very) short description - the majority will be hosted on line but the best will make it into the printed journal. Any such submissions should be submitted through the website as normal and will be peer reviewed.

${ }^{1}$ Academic Department of Military Surgery and Trauma, Royal Centre for Defence Medicine, Birmingham, UK; ${ }^{2}$ Department of Surgery, Rotherham NHS Foundation Trust, Rotheram, UK

Correspondence to I Garner, Department of Surgery, Rotherham NHS Foundation Trust, Rotheram, UK; editor.jramc@bmjgroup.com

\section{AFGHANISTAN'S AFTERIMATH}

Now two years after the drawdown of operations in Afghanistan, we are still searching through the data that the campaign provided and taking the opportunities to review how we performed. Two articles in this edition look at surgical Key Performance Indicators for the deployed trauma teams and suggest modifications and those who Died of Wounds after arriving at medical treatment facilities in both Afghanistan and Iraq.

\section{TRAINING FOR TRAUMA SURGERY}

The perennial problem of how to prepare for war surgery during peacetime is addressed this time by the French Military who describe their course which seems to bear many similarities to our own Military Operational Surgical Training (MOST) course.

\section{ETHICAL CONCERNS}

The changing face of the contingency environment raises many ethical issues and much work is ongoing to work out how they can be best addressed; but there still remain ethical challenges from the last ten years of deployments and terrorism. Two articles touch on this: the review of blood borne virus transmission after terrorist attacks and a Personal View of the ethical challenges of repatriations.

\section{- AND FINALLY}

It is pleasing to see that the article by Mortelmans et al confirms what many of us have long believed to be true; namely that having a military background as a medical student prepares you better to deal with the unexpected challenges that something such as a terrorist event may throw at you.

\section{Competing interests None declared.}

Provenance and peer review Not commissioned; internally peer reviewed.

To cite Breeze J, Garner J. J R Army Med Corps 2016;162:317.

J R Army Med Corps 2016;162:317.

doi:10.1136/jramc-2016-000719 